\title{
Enzyme Activities of Five White-Rot Fungi in the Presence of Nanocellulose
}

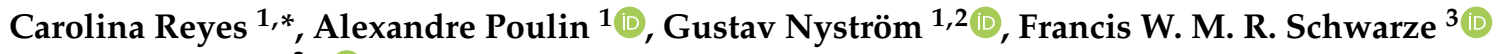 \\ and Javier Ribera ${ }^{3, *}$ (D) \\ 1 Laboratory for Cellulose \& Wood Materials, Empa, Überlandstrasse 129, 8600 Dübendorf, Switzerland; \\ alexandre.poulin@gmail.com (A.P.); gustav.nystroem@empa.ch (G.N.) \\ 2 Department of Health Science and Technology, ETH Zürich, Schmelzbergstrasse 9, 8092 Zürich, Switzerland \\ 3 Laboratory for Cellulose \& Wood Materials, Empa, Lerchenfeldstrasse 5, 9014 St. Gallen, Switzerland; \\ Francis.Schwarze@empa.ch \\ * Correspondence: creyes6@gmail.com (C.R.); javier.ribera@empa.ch (J.R.)
}

Citation: Reyes, C.; Poulin, A.; Nyström, G.; Schwarze, F.W.M.R.; Ribera, J. Enzyme Activities of Five White-Rot Fungi in the Presence of Nanocellulose. J. Fungi 2021, 7, 222. https://doi.org/10.3390/jof7030222

Academic Editor: Laurent Dufossé

Received: 16 February 2021

Accepted: 12 March 2021

Published: 18 March 2021

Publisher's Note: MDPI stays neutral with regard to jurisdictional claims in published maps and institutional affiliations.

Copyright: (c) 2021 by the authors. Licensee MDPI, Basel, Switzerland. This article is an open access article distributed under the terms and conditions of the Creative Commons Attribution (CC BY) license (https:// creativecommons.org/licenses/by/ $4.0 /)$.

\begin{abstract}
White-rot fungi can degrade all lignocellulose components due to their potent lignin and cellulose-degrading enzymes. In this study, five white-rot fungi, Trametes versicolor, Trametes pubescens, Ganoderma adspersum, Ganoderma lipsiense, and Rigidoporus vitreus were tested for endoglucanase, laccase, urease, and glucose-6-phosphate (G6P) production when grown with malt extract and nanocellulose in the form of TEMPO (2,2,6,6-tetramethylpiperidine-1-oxyl radical) oxidized cellulose nanofibrils (CNF) and cellulose nanocrystals (CNC). Results show that temperature plays a key role in controlling the growth of all five fungi when cultured with malt extract alone. Endoglucanase activities were highest in cultures of G. adspersum and G. lipsiense and laccase activities were highest in cultures of T. versicolor and R. vitreus. Urease activities were highest in cultures of G. adspersum, $G$. lipsiense, and R. vitreus. Glucose-6-phosphate levels also indicate that cells were actively metabolizing glucose present in the cultures. These results show that TEMPO-oxidized CNF and CNC do not inhibit the production of specific lignocellulose enzymes by these white-rot fungi. The apparent lack of enzymatic inhibition makes TEMPO-oxidized CNF and CNC excellent candidates for future biotechnological applications in combination with the white-rot fungi studied here.
\end{abstract}

Keywords: lignocellulosic enzymes; TEMPO; cellulose; CNC; CNF; Trametes; Ganoderma; Rigidoporus

\section{Introduction}

White-rot fungi, with the ability to degrade lignocellulosic material, are valued in the paper, textile, and food industries for their ability to produce various lignocellulosicdegrading enzymes [1-3]. These fungi differ from brown-rot in that they can degrade all lignocellulose constituents (lignin, cellulose, and hemicellulose) producing $\mathrm{CO}_{2}$ as a byproduct of this metabolism [4,5]. Among the hydrolytic enzymes produced by white-rot fungi, to degrade the cellulose component of lignocellulosic material, are the endoglucanases. These enzymes are capable of cleaving the $\beta$-1,4-glycosidic linkages of glucose units that make up cellulose into cellobiose and cellulooligosaccharides [6]. Other hydrolytic enzymes used by white-rot fungi include: cellobiohydrolases, $\beta$-glucosidases, and lytic polysaccharide monooxygenases [6,7]. To degrade lignin, white-rot fungi use lignin peroxidase, manganese peroxidase, and laccase [8]. Laccases are a copper containing enzyme used by white-rot fungi to oxidize a variety of aromatic hydrogen polyphenols and non-phenolic compounds [8].

Previous studies have shown that the production of lignocellulosic enzymes by whiterot fungi depends on many factors like the strain of fungi, carbon and nitrogen substrate, and crystallinity of the cellulose [7,9-13]. In certain white-rot fungi, glucose and other simple sugar molecules can inhibit cellulase production [14,15]. Additionally, certain nitrogen compounds can stimulate cellulase and laccase production in some white-rot 
fungi $[11,16,17]$. Satyamurthy et al. [9] hypothesized that due to their highly anionic charge, cellulose nanocrystals prepared by sulfuric acid hydrolysis would inhibit fungal growth. In their study, the growth of Trichoderma reesei was inhibited by cellulose nanocrystals compared to when they were grown with cellulose prepared by microbial hydrolysis. In addition, the fungus produced less cellulases when grown with cellulose nanofibrils, prepared by high-pressure homogenization processes. However, other studies focused on the use of cellulose nanocrystals and nanofibrillated cellulose materials for bioengineering applications, have found these types of materials do not inhibit the metabolic activities of other types of microorganisms including cyanobacteria and algae [18].

In this study, our aim was to determine the effect of TEMPO (2,2,6,6-tetramethylpiperid ine-1-oxyl radical) oxidized cellulose nanofibrils (CNF) and cellulose nanocrystals (CNC) on the endoglucanase, laccase and urease activities of five different white-rot basidiomycetes fungi when incubated with this material in malt extract medium. Additionally, glucose catabolism was investigated by analyzing glucose-6-phosphate (G6P) concentrations. TEMPO-oxidized $\mathrm{CNF}$ and $\mathrm{CNC}$ material were selected for this study because of their potential application in manufacturing bio-based hydrogels with wood decay fungi. As such, it would be important to determine whether the material is harmful to various filamentous fungi being considered for this future application. Additionally, it would be important to determine whether the fungi can produce enzymes that could potentially degrade TEMPO-oxidized CNF and CNC as an attractive bio-degradative feature. Given recent findings showing that the manufacturing cost of TEMPOoxidized CNF can be reduced by decreasing TEMPO in the production process [19], the use of this material along with $\mathrm{CNC}$ for future biotechnological applications appears economically feasible. We hypothesized that TEMPO-oxidized CNF and CNC would not inhibit enzyme production by white-rot fungi. To our knowledge, this is the first study to characterize various white-rot basidiomycetes in the presence of TEMPO-oxidized CNF and CNC.

\section{Materials and Methods}

\subsection{Fungal Growth Rate Experiments}

Prior to initiating the growth experiments of fungi in the presence of cellulose, the optimal growth parameters were first established. Five fungal strains were used for all subsequent experiments mentioned in the manuscript including Trametes versicolor (Empa strain 159), T. pubescens (Empa strain 220), Ganoderma adspersum (Empa strain 003), G. lipsiense (Empa strain 646) [20,21], and Rigidoporus vitreus (Empa strain 643) [22,23]. The taxonomic identity of the fungi is based on mycobank (http:/ / www.mycobank.org, accessed on 15 February 2021), the most frequently used online registry for nomenclature repositories. Fungi were grown in malt extract agar [MEA] (Oxoid) or glucose agar at $1 \%$, $2 \%$, and $4 \%(w / v)$. They were incubated at various relative humidity levels $(60 \%, 70 \%$, and $80 \%$ ) and temperatures $\left(15^{\circ} \mathrm{C}, 20^{\circ} \mathrm{C}, 25^{\circ} \mathrm{C}\right.$, and $\left.30^{\circ} \mathrm{C}\right)$. The $\mathrm{pH}$ experiments were conducted in $2 \%(w / v)$ MEA at $80 \%$ relative humidity and $25^{\circ} \mathrm{C}$. The $\mathrm{pH}$ of the media was adjusted with $1 \mathrm{M} \mathrm{HCl}$ and $0.1 \mathrm{M} \mathrm{NaOH}$. The media was prepared using sterile, distilled water, and all fungal cultures were incubated in the dark.

\subsection{Fungal Enzyme Experiments}

For the enzymatic experiments, fungi were grown in $70 \mathrm{~mL}$ liquid malt extract media (ME) supplemented with $1 \mathrm{~g}$ TEMPO-oxidized CNF (1.2 wt \%) and sulfuric acid hydrolyzed CNC (15 wt\%) giving a final CNF and CNC concentration of $0.017 \mathrm{wt} \%$ and $0.2 \mathrm{wt} \%$ respectively. The TEMPO-oxidized CNF was prepared as previously described $[24,25]$ and added to commercially purchased cellulose nanocrystals (CNC) (Celluforce, Canada). The media was prepared using water with a resistivity $\geq 18 \mathrm{M} \Omega \mathrm{cm}^{-2}$. Cultures that were shaken throughout the experiment were continuously agitated at $120 \mathrm{rpm}$ in the dark. Cultures left standing were initially agitated at $120 \mathrm{rpm}$ for 2 days, to promote the growth of the fungi, and then left to stand in the dark for the rest of the experiment. At different time intervals, $1.5 \mathrm{~mL}$ of supernatant was removed, centrifuged at 10,000 rpm for $10 \mathrm{~min}$ to remove any cell biomass. The centrifuged supernatants were transferred to new test tubes and the tubes were frozen at $-20{ }^{\circ} \mathrm{C}$ for further analysis. 


\subsection{Endoglucanase Assay}

The following method is based on modifications to previously described methods [26-28]. Fifty microliters of sample (undiluted or diluted in $50 \mathrm{mM}$ acetate buffer $\mathrm{pH}$ 5) were mixed with $450 \mu \mathrm{L}$ of $0.05 \%(w / v)$ medium viscosity carboxymethylcellulose (CMC) reagent (SigmaAldrich, Buchs, Switzerland) and the tube heated to $50{ }^{\circ} \mathrm{C}$ for $10 \mathrm{~min}$. A substrate blank was also prepared consisting of $450 \mu \mathrm{L} \mathrm{CMC}$ and $50 \mu \mathrm{L}$ acetate buffer. Afterward, $100 \mu \mathrm{L}$ of this mixture was transferred to a new tube and to this, $200 \mu \mathrm{L}$ of $1 \%(w / v)$ cyanoacetamide and $1 \mathrm{~mL}$ of borate (100 mM pH 9) was added. The samples were heated to $80^{\circ} \mathrm{C}$ and then left to cool for at least $40 \mathrm{~min}$ before proceeding to measure the ultraviolet (UV) absorbance at the wavelength of $276 \mathrm{~nm}$ using a quartz cuvette and a Genyses 10S UV visible spectrophotometer. Glucose standards (20 mM stock solution) were prepared in $50 \mathrm{mM}$ acetate buffer ( $\mathrm{pH}$ 9) including: $0 \mathrm{mM}, 0.1 \mathrm{mM}, 0.25 \mathrm{mM}, 0.5$, and $1-6 \mathrm{mM}$ standards. Following preparation of the standards, $100 \mu \mathrm{L}$ of the standard solution was transferred to a new tube, and $1 \%(w / v)$ cyanoacetamide and borate were added as described above for the samples. Enzyme activities are reported as international units (IU) which are defined as the amount of enzyme that releases $1 \mu \mathrm{mol}$ of reducing sugars per min. The IU was determined by converting $\mathrm{mM}$ of reduced glucose to $\mu \mathrm{mol} / \mathrm{mL}$ and the resulting value was divided by the assay time.

\subsection{Laccase Assay}

This method is based on previously published methods [29,30]. For this assay, $700 \mu \mathrm{L}$ of citrate buffer ( $\mathrm{pH} 4.5$ ) and $100 \mu \mathrm{L}$ of 2,2'-azino-bis(3-ethylbenzothiazoline-6-sulfonic acid) [ABTS] were added to a quartz cuvette and then $200 \mu \mathrm{L}$ of sample (undiluted or diluted in citrate buffer) was added to the cuvette. The mixture was pipetted up and down and the UV absorbance was immediately measured using a Genyses $10 \mathrm{~S}$ UV visible spectrophotometer. Samples were measured at $10 \mathrm{~s}$ intervals for $3 \mathrm{~min}$ at the wavelength of $420 \mathrm{~nm}$. Enzyme activities are reported as units per liter $(\mathrm{U} / \mathrm{L})$ and were calculated using the following formula:

$$
\frac{U}{L}=\frac{(\Delta E \cdot V t)}{\epsilon x d \cdot V s}
$$

where $\Delta E$ is the change in the extinction of light $\left[\mathrm{min}^{-1}\right]$ at the wavelength of $420 \mathrm{~nm}, \epsilon$ is the molar absorption coefficient of ABTS at $\mathrm{pH} 9\left[36 \mathrm{mM} \mathrm{cm}^{-1}\right], d$ is the thickness of the quartz cuvette $(1 \mathrm{~cm}), V t$ is the total volume measured, and vs. is the volume of the enzyme stock solution.

\subsection{Urease Assay}

Urease activities in standing cultures were investigated using the Urease Activity Assay Kit (Sigma-Aldrich, Buchs, Switzerland). Briefly, the kit quantitates ammonia produced from the hydrolysis of urea by urease present in samples. Ammonia, in turn, is revealed by the Berthelot method [31] by measuring the absorbance of the sample at the wavelength of $670 \mathrm{~nm}$. One unit of urease corresponds to the amount of enzyme that catalyzes the formation of $1 \mu$ mole of ammonia per min at $\mathrm{pH} 7$.

\subsection{Glucose-6-Phosphate Assay}

Glucose catabolism was studied in standing cultures by measuring G6P, one key intermediate for glucose transport into cells, using the Amplite ${ }^{\mathrm{TM}}$ Colorimetric Glucose-6Phosphate Assay Kit (AAT Bioquest ${ }^{\circledR 囚}$, LubioScience $\mathrm{GmbH}$, Zürich, Switzerland) according to the manufacturer's instructions.

\section{Results}

\subsection{Growth Optima T. versicolor 159}

T. versicolor 159 grew optimally at $70 \%$ and $80 \%$ relative humidity in 1 and $2 \%(w / v)$ MEA (Figures $1 \mathrm{~A}$ and S1A-C). In the temperature experiments, its growth rate was highest at $25{ }^{\circ} \mathrm{C}$ and $30{ }^{\circ} \mathrm{C}$ (Figures $1 \mathrm{~B}$ and S1D-G). The $\mathrm{pH}$ curves for T. versicolor 159 were 
similar indicating that this factor is not critical for growth in 2\% $(w / v)$ MEA at $80 \%$ relative humidity and $25^{\circ} \mathrm{C}$ (Figures $1 \mathrm{C}$ and $\mathrm{S} 1 \mathrm{H}$ ).

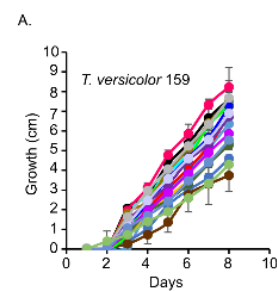

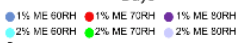

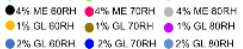

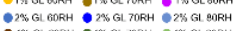

D.
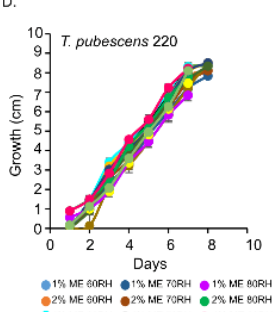

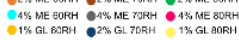

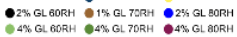

G.

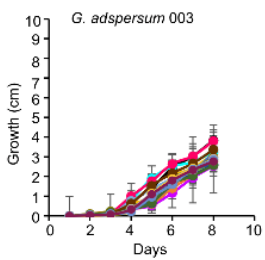

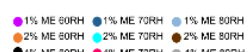

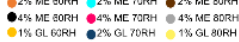

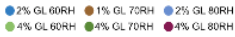

J.

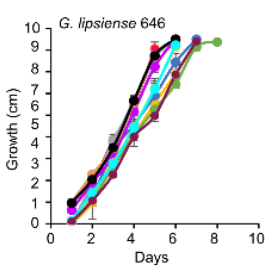

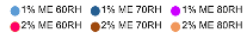

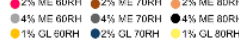

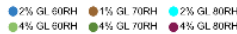

M.

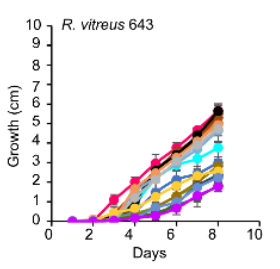

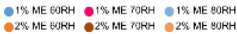

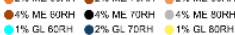

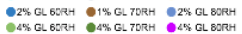

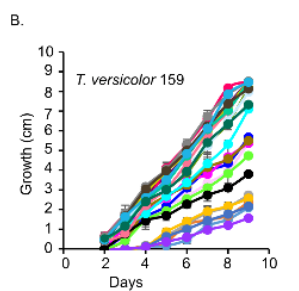

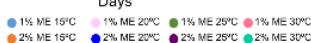

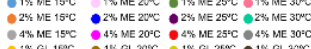

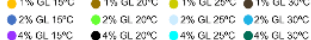

E.

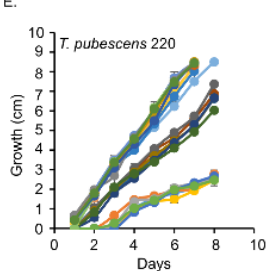

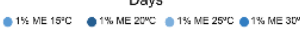

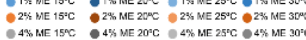

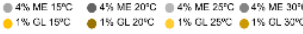

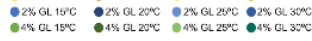

$\mathrm{H}$.

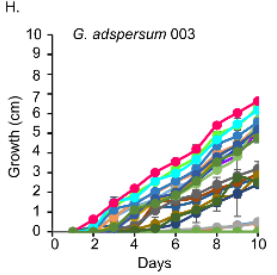

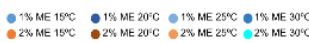

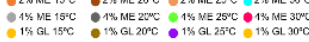

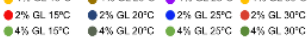

k.

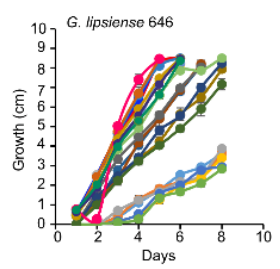

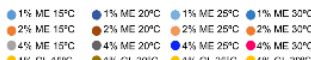

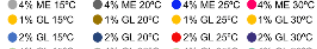

N

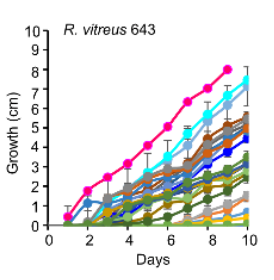

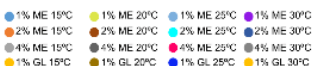

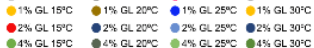
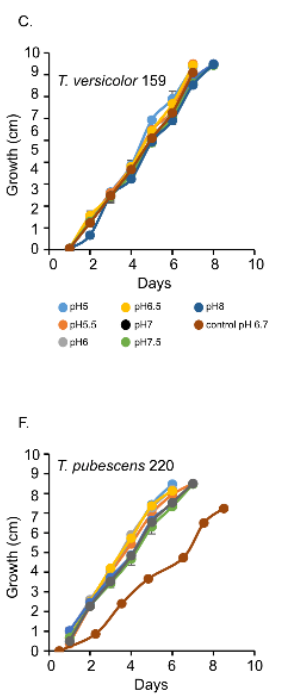

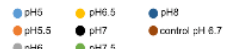

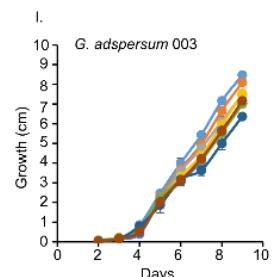

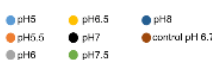

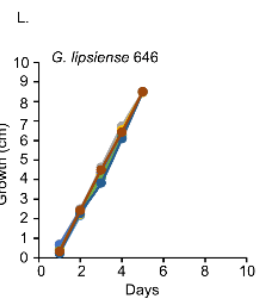

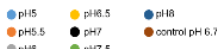

o.

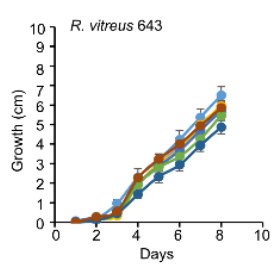

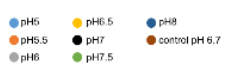

Figure 1. Growth rates of white rot fungi in the presence of different percentages of malt extract (ME) and glucose (GL). (A,D,G,J,M) show the growth of fungi at various percent relative humidities (RH). $(\mathbf{B}, \mathbf{E}, \mathbf{H}, \mathbf{K}, \mathbf{N})$ show the growth of fungi at various temperatures. $(\mathbf{C}, \mathbf{F}, \mathbf{I}, \mathbf{L}, \mathbf{O})$ show the growth of fungi at various $\mathrm{pHs}$. Data represent an average of $\geq 5$ biological replicates. 


\subsection{Growth Optima T. pubescens 220}

T. pubescens 220 grew well at all relative humidity levels in MEA or glucose ( Figures 1D and S2A-C). In the temperature experiments, T. pubescens 220 grew best at $25^{\circ} \mathrm{C}$ and $30{ }^{\circ} \mathrm{C}$ in 2 and $4 \%(w / v)$ MEA and in 1 and $2 \%(w / v)$ glucose (Figures $1 \mathrm{E}$ and S2D-G). With the exception of $\mathrm{pH} 6.7$, T. pubescens 220 grew optimally at all $\mathrm{pHs}$ (Figures 1F and S2H).

\subsection{Growth Optima G. adspersum 003 and G. lipsiense 646}

G. adspersum grew optimally at all relative humidities in MEA and glucose (Figures 1B and S3A-C). In the temperature experiments, its growth rate was highest at $25^{\circ} \mathrm{C}$ or $30^{\circ} \mathrm{C}$ in $2 \%$ and $4 \%(w / v)$ MEA (Figures $1 F$ and S3D-G). G. lipsiense 646 grew best at $60 \%$ and $80 \%$ relative humidity in $4 \%(w / v)$ MEA and in $1 \%$ and $2 \%(w / v)$ glucose (Figures $1 \mathrm{~J}$ and S4A-C). The growth rate of $G$. lipsiense 646 was highest at $30{ }^{\circ} \mathrm{C}$ also when grown in $4 \%$ $(w / v)$ MEA and 1 and $2 \%(w / v)$ glucose (Figures $1 \mathrm{~K}$ and S4D-G). Both Ganoderma spp. grew optimally at all pHs (Figure 1I,L; Figures $\mathrm{S} 3 \mathrm{H}$ and $\mathrm{S} 4 \mathrm{H}$ ).

\subsection{Growth Optima R. vitreus}

$R$. vitreus 643 had the highest growth rate at $70 \%$ relative humidity (Figures $1 \mathrm{M}$ and S5A-C). In the temperature experiments, it grew best at $25^{\circ} \mathrm{C}$ in $4 \%(w / v)$ MEA (Figures $1 \mathrm{~N}$ and $\mathrm{S} 5 \mathrm{D}-\mathrm{G}$ ). It grew optimally at $\mathrm{pH} 5$ (Figures $1 \mathrm{O}$ and $\mathrm{S} 5 \mathrm{H}$ ).

\subsection{Endoglucanase Assays}

Overall, samples that were shaking throughout most of the experiment in the presence of TEMPO-oxidized CNF $(0.017 \mathrm{wt} \%)$ and CNC $(0.2 \mathrm{wt} \%)$ had the lowest endoglucanase activities compared to those that were cultured under non-shaking conditions (Figure 2A,B). For example, at the end of the experiment, shaking cultures of G. adspersum 003, G. lipsiense 646, and $R$. vitreus 643 showed the highest endoglucanase activity $(\sim 23 \pm 2 \mathrm{U} / \mathrm{mL}$, $\sim 16 \pm 4 \mathrm{U} / \mathrm{mL}$ and $\sim 15 \pm 5 \mathrm{U} / \mathrm{mL}$ respectively) compared to T. versicolor $159(\sim 6 \pm 2 \mathrm{U} / \mathrm{mL})$ and T. pubescens $220(\sim 8 \pm 4 \mathrm{U} / \mathrm{mL})$. Under non-shaking conditions, G. lipsiense 646, G. adspersum 003, and R. vitreus 643 had the highest endoglucanase activity (Figure 3B). At the end of the experiment, the enzyme activities of G. lipsiense 646, G. adspersum 003, and $R$. vitreus 646 were $\sim 42 \pm 9 \mathrm{U} / \mathrm{mL}, \sim 34 \pm 2 \mathrm{U} / \mathrm{mL}$, and $\sim 21 \pm 1 \mathrm{U} / \mathrm{mL}$ respectively. Enzyme activities of. T. versicolor $159(\sim 20 \pm 5 \mathrm{U} / \mathrm{mL})$ and T. pubescens $220(16 \pm 3 \mathrm{U} / \mathrm{L})$ were lower in comparison to the above fungi.

\subsection{Laccase Assays}

Laccase activity assays showed a similar trend as the endoglucanase experiments. Samples that were shaken had lower laccase activities compared to those that were left standing throughout the experiment (Figure 3A,B). R. vitreus 643 and T. versicolor 159 had the highest laccase activity under both conditions. Under shaking conditions at the end of the experiment, enzyme activities for R. vitreus 643 and T. versicolor 159 were $238 \pm 32 \mathrm{U} / \mathrm{L}$ and $225 \pm 79 \mathrm{U} / \mathrm{L}$. This is in contrast to the lower enzyme activities of T. pubescens 220 $(\sim 110 \pm 71 \mathrm{U} / \mathrm{L})$, G. adspersum $003(\sim 19 \pm 14 \mathrm{U} / \mathrm{L})$, and G. lipsiense $646(\sim 2 \pm 1 \mathrm{U} / \mathrm{L})$. At the end of the experiments under static conditions, their activities were $\sim 603 \pm 75 \mathrm{U} / \mathrm{L}$ and $\sim 351 \pm 35 \mathrm{U} / \mathrm{L}$ respectively. In comparison, G. adspersum 003, T. pubescens 220 , and G. lipsiense 646 had lower enzyme activities $(\sim 95 \pm 31 \mathrm{U} / \mathrm{L}, \sim 30 \pm 16 \mathrm{U} / \mathrm{L}$, and $\sim 4 \pm 0 \mathrm{U} / \mathrm{L}$ respectively). 
A.

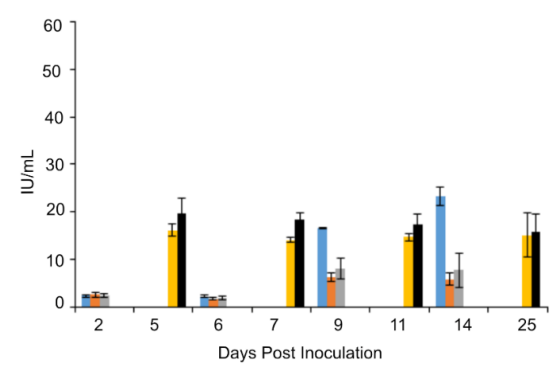

B.

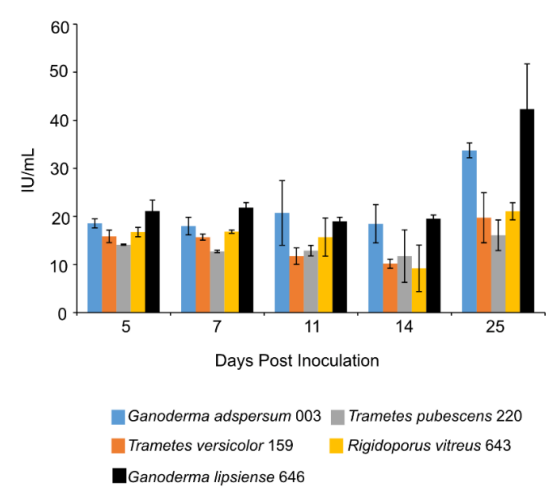

Figure 2. Endoglucanase activity at different days of incubation period of various white rot fungi when incubated with $2 \%(w / v)$ malt extract and TEMPO-oxidized CNF $(0.017 \mathrm{wt} \%)$ and $\mathrm{CNC}(0.2 \mathrm{wt} \%)$ at $25{ }^{\circ} \mathrm{C}$ and $80 \%$ relative humidity. (A) Cultures were shaken at $120 \mathrm{rpm}$ during incubation. (B) Cultures were initially shaken to stimulate growth but after 2 days they were left to stand for the duration of the experiment. Data represent an average of three biological replicates.

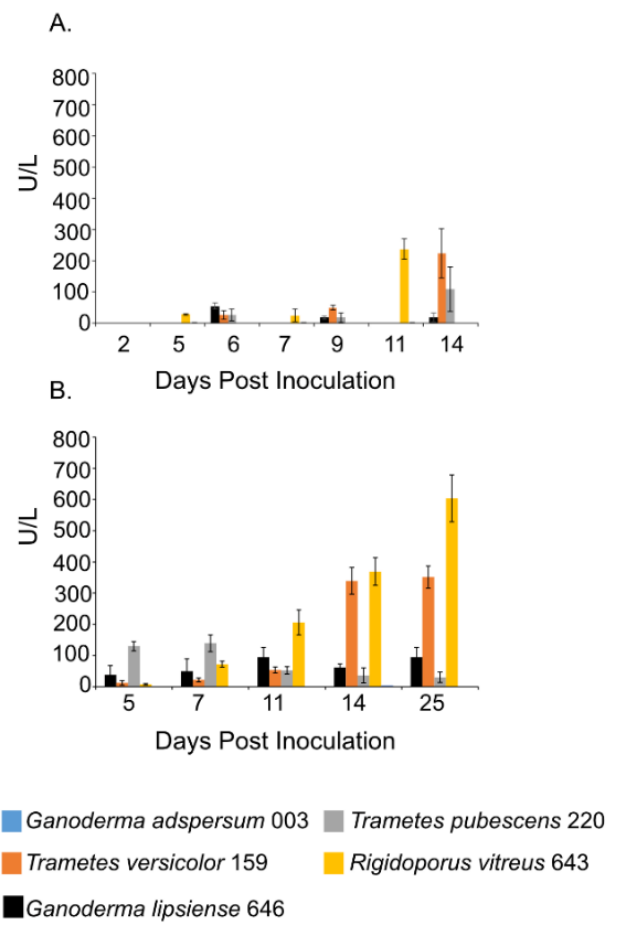

Figure 3. Laccase activity at different days of incubation period of various white rot fungi when incubated with $2 \%(w / v)$ malt extract and TEMPO-oxidized $\mathrm{CNF}(0.017 \mathrm{wt} \%)$ and $\mathrm{CNC}(0.2 \mathrm{wt} \%)$ at $25{ }^{\circ} \mathrm{C}$ and $80 \%$ relative humidity. (A) Cultures were shaken at $120 \mathrm{rpm}$ during incubation. (B) Cultures were initially shaken to stimulate growth but after 2 days they were left to stand for the duration of the experiment. Data represent an average of three biological replicates. 


\subsection{Urease Assay}

At 11 days post-inoculation, the activity of urease in all standing culture samples increased and remained stable through day 14 (Figure 4). After 25 days, urease activity was highest in cultures of G. adspersum 003 (284 $\pm 36 \mathrm{U} / \mathrm{L})$, G. lipsiense $646(246 \pm 20 \mathrm{U} / \mathrm{L})$, and $R$. vitreus $646(258 \pm 4 \mathrm{U} / \mathrm{L})$.

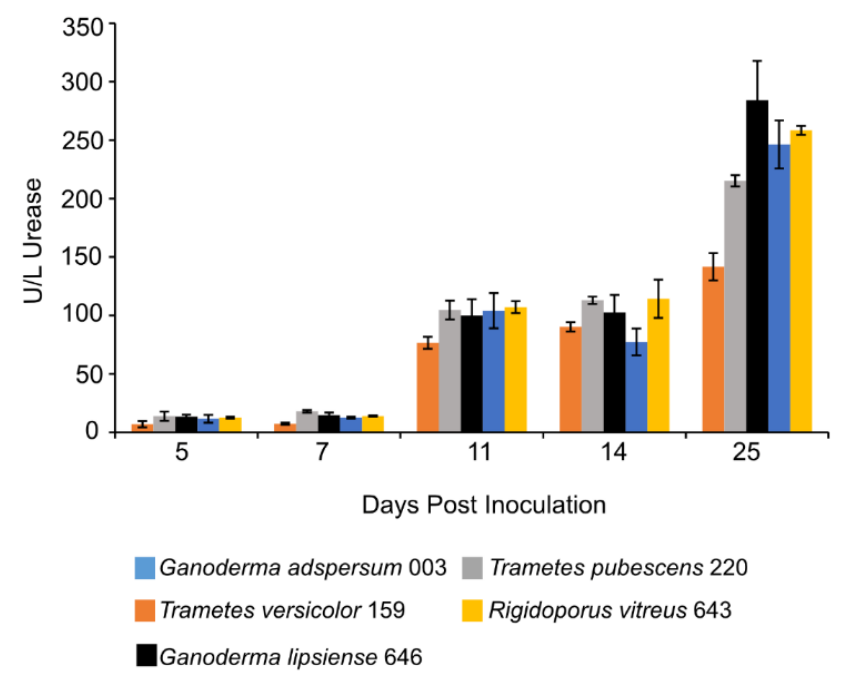

Figure 4. Urease activity at different days of incubation period of various white rot fungi when incubated with $2 \%(w / v)$ malt extract and TEMPO-oxidized CNF( $0.017 \mathrm{wt} \%)$ and CNC $(0.2 \mathrm{wt} \%)$ at $25{ }^{\circ} \mathrm{C}$ and $80 \%$ relative humidity. Cultures were initially shaken to stimulate growth but after 2 days they were left to stand for the duration of the experiment. Data represent an average of three biological replicates.

\subsection{Glucose Assay}

Concentrations of G6P increased in all standing cultures at 11 days post-inoculation and remained constant throughout the experiment (Figure 5). G6P concentrations ranged between $29 \pm 1 \mu \mathrm{M}$ measured in cultures of $R$. vitreus 643 and $36 \pm 3 \mu \mathrm{M}$ measured in cultures of $G$. adspersum 003.

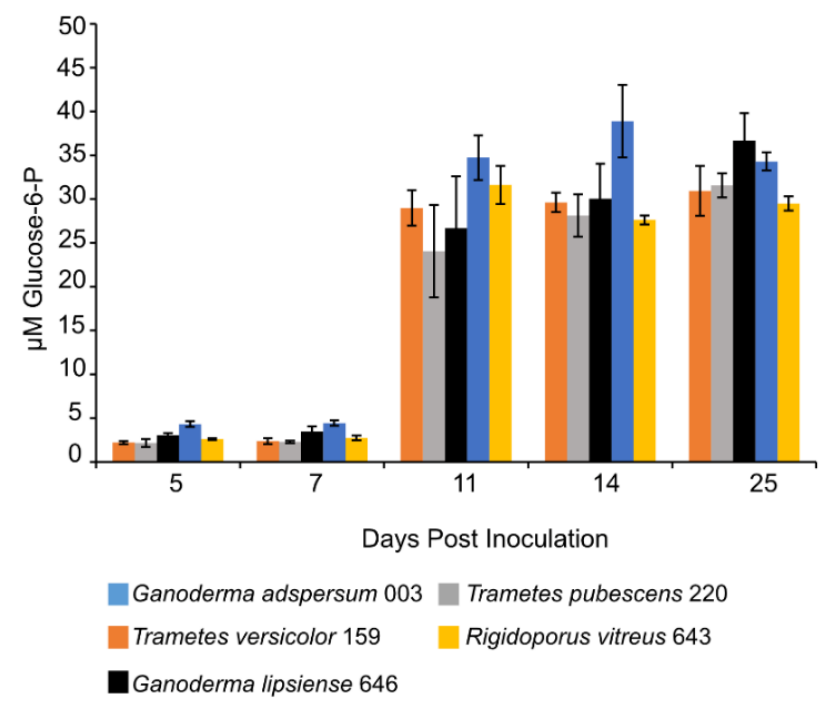

Figure 5. Glucose-6-P concentration at different days of incubation period of various white rot fungi when incubated with $2 \%(w / v)$ malt extract and TEMPO-oxidized CNF $(0.017 \mathrm{wt} \%)$ and CNC $(0.2 \mathrm{wt} \%)$ at $25{ }^{\circ} \mathrm{C}$ and $80 \%$ relative humidity. Cultures were initially shaken to stimulate growth but after 2 days they were left to stand for the duration of the experiment. Data represent an average of three biological replicates. 


\section{Discussion}

In this study, we addressed the hypothesis that TEMPO-oxidized CNF and CNC would not interfere with enzyme production by five white-rot fungi when exposed to this material during cell growth. To this end, we first optimized the growth conditions of the fungi on MEA before exposing fungi to TEMPO-oxidized CNF and CNC. Results from the growth experiments on MEA support findings from previous studies [32-35] showing that MEA, temperatures between $25-30{ }^{\circ} \mathrm{C}$, and a broad $\mathrm{pH}$ range are optimal growth conditions for T. versicolor 159, T. pubecens 220, G. adspersum 003, G. lipsiense 646, and $R$. vitreus 643 strains. Temperatures $\leq 20^{\circ} \mathrm{C}$ slowed down the growth of these fungi irrespective of the media demonstrating that temperature is a key factor controlling their growth and activity. Previous studies have shown that the type of carbon and nitrogen sources and their concentrations can influence the mycelial growth and polysaccharide production by white-rot fungi $[36,37]$. In addition to maltose, other carbohydrates typically present in MEA include fructose, glucose, and sucrose [38]. MEA is also rich in nitrogenous compounds like peptides, tryptophan, tyrosine, and vitamins [38,39]. Thus, the higher growth rates observed when fungi were grown in MEA vs. the glucose media were likely due to the greater availability of carbon and nitrogen substrates present in the MEA.

Having established the optimal growth conditions, we analyzed the activity of various enzymes in cultures incubated with $2 \%(w / v)$ MEA TEMPO-oxidized CNF $(0.017 \mathrm{wt} \%)$ and CNC $(0.2 \mathrm{wt} \%)$. Endoglucanase activity was analyzed due to its ability to cleave the $\beta-1-4$ linkages of cellulose [6]. The higher endoglucanase activities observed in the cultures left to stand compared to those that were left shaking throughout the duration of the experiments could be due to greater contact time between the fungal cells and cellulose. Fungal cells left to stand would have uninterrupted contact with the TEMPO-oxidized CNF and CNC material compared to shaking cultures. Better cell contact with the cellulose material could in turn trigger increased enzyme production associated with cellulose degradation. A similar hypothesis was put forward in studies involving lignin degradation by standing cultures of white-rot fungi [40]. Another explanation is that cells that are cultured under shaking conditions during growth are more dispersed and fragmented compared to cells that are left standing and this morphological difference could influence enzyme production. The influence of fungal morphology on the fungal secretion of products has been shown to vary between fungi [41]. Some fungi produce more of one product type when left undisturbed during growth while others produce more enzymes in the same conditions. Alternatively, shaking conditions could have lowered endoglucanase activity. Previous studies spanning several decades of research have observed that shaking or agitation can decrease cellulase activities in extracts from fungi [42-44] or in the culture producing the cellulase [45]. Various hypotheses have been put forward as to why this may occur, including possible shear stress on the cellulase.

Comparison of endoglucanase activities in the presence of TEMPO-oxidized CNF and $\mathrm{CNC}$ with other white-rot fungi exposed to cellulose materials showed the fungi in this study produced endoglucanase levels comparable to those in the Metreveli et al. [46] and Liu et al. [47] studies. The white-rot fungi in this study also produced higher levels of endoglucanase than those reported in the Satyamurthy et al. 2016 study (Table 1). Thus, TEMPO-oxidized CNF and CNC did not appear to inhibit endoglucanase production by white-rot fungi in this study. On the contrary, it appears to stimulate enzyme production comparable to lignocellulosic material. 
Table 1. Comparison of endoglucanase activities of fungi grown in the presence of crystalline cellulose or wood.

\begin{tabular}{|c|c|c|c|}
\hline Fungus & Growth Conditions & Endoglucanase Activity & Study \\
\hline $\begin{array}{c}\text { Pycnoporus. coccineus } 310 \\
\text { (Basidiomycota) }\end{array}$ & $\begin{array}{l}\text { 1.5\% micro crystalline cellulose } \\
\text { (Avicel medium) }\left(150 \mathrm{rpm}, 27^{\circ} \mathrm{C}\right)\end{array}$ & $65.6 \pm 7.3 \mathrm{U} / \mathrm{mL}$ (14 days) & Metreveli et al. [46] \\
\hline $\begin{array}{l}\text { Schizophyllum commune } 632 \\
\text { (Basidiomycota) }\end{array}$ & $\begin{array}{l}\text { 1.5\% micro crystalline cellulose } \\
\text { (Avicel medium) }\left(150 \mathrm{rpm}, 27^{\circ} \mathrm{C}\right)\end{array}$ & $28 \pm 3.9 \mathrm{U} / \mathrm{mL}$ (14 days) & Metreveli et al. [46] \\
\hline $\begin{array}{l}\text { Trametes hirusta } 17 \\
\text { (Basidiomycota) }\end{array}$ & $\begin{array}{l}\text { 1.5\% micro crystalline cellulose } \\
\text { (Avicel medium) }\left(150 \mathrm{rpm}, 27^{\circ} \mathrm{C}\right)\end{array}$ & $34.3 \pm 3.1 \mathrm{U} / \mathrm{mL}$ (14 days) & Metreveli et al. [46] \\
\hline $\begin{array}{l}\text { Irepex lacteus } 104 \\
\text { (Basidiomycota) }\end{array}$ & $\begin{array}{l}\text { 1.5\% micro crystalline cellulose } \\
\text { (Avicel medium) }\left(150 \mathrm{rpm}, 27^{\circ} \mathrm{C}\right)\end{array}$ & $51.7 \pm 4.3 \mathrm{U} / \mathrm{mL}$ (14 days) & Metreveli et al. [46] \\
\hline $\begin{array}{l}\text { Trichoderma viride } \\
\text { (Ascomycota) }\end{array}$ & $\begin{array}{l}2 \% \text { commercial microcrystalline } \\
\text { cellulose (Mandel's medium) } \\
\left(150 \mathrm{rpm}, 30^{\circ} \mathrm{C}\right)\end{array}$ & 22 U/mL (15 days) & Liu et al. [47] \\
\hline $\begin{array}{l}\text { Aspergillus niger } \\
\text { (Ascomycota) }\end{array}$ & $\begin{array}{l}2 \% \text { commercial microcrystalline } \\
\text { cellulose (Mandel's medium) } \\
\left(150 \mathrm{rpm}, 30^{\circ} \mathrm{C}\right)\end{array}$ & 9 U /mL (15 days) & Liu et al. [47] \\
\hline $\begin{array}{l}\text { Trichoderma koningii } \\
\quad \text { (Ascomycota) }\end{array}$ & $\begin{array}{l}2 \% \text { commercial microcrystalline } \\
\text { cellulose (Mandel's medium) } \\
\left(150 \mathrm{rpm}, 30^{\circ} \mathrm{C}\right)\end{array}$ & 32 U /mL (15 days) & Liu et al. [47] \\
\hline $\begin{array}{l}\text { Trichoderma reseei } \\
\text { (Ascomycota) }\end{array}$ & $\begin{array}{l}2 \% \text { commercial microcrystalline } \\
\text { cellulose (Mandel's medium) } \\
\left(150 \mathrm{rpm}, 30^{\circ} \mathrm{C}\right)\end{array}$ & $\sim 5 \mathrm{U} / \mathrm{mL}$ (15 days) & Liu et al. [47] \\
\hline $\begin{array}{l}\text { Trichoderma reseei } \\
\text { (Ascomycota) }\end{array}$ & $\begin{array}{l}\text { Nanocellulose prepared by microbial } \\
\text { hydrolysis (Mandel's medium) }\end{array}$ & $\begin{array}{l}\sim 0.04 \mathrm{IU} / \mathrm{mL} \text { (Day 1) } \\
\sim 0.16 \mathrm{IU} / \mathrm{mL} \text { (Day 5) }\end{array}$ & Satyamurthy et al. [9] \\
\hline $\begin{array}{l}\text { Trichoderma reseei } \\
\text { (Ascomycota) }\end{array}$ & Nanofibrilliated cellulose (NFC) & $\sim 0.02 \mathrm{IU} / \mathrm{mL}$ (Day 1) & Satyamurthy et al. [9] \\
\hline $\begin{array}{l}\text { Aspergillus niger } \\
\text { (Ascomycota) }\end{array}$ & $\begin{array}{l}0.3 \% \text { nanocellulose prepared by } \\
\text { microbial hydrolysis (Mandel's } \\
\text { medium) }\end{array}$ & 0.2 IU /mL (Day 5) & Satyamurthy et al. [9] \\
\hline $\begin{array}{l}\text { Trametes versicolor }(\mathrm{L}) \\
\text { Loyd (CTB 863A) }\end{array}$ & $\begin{array}{l}\text { Birch wood } \\
(5 \% \text { malt extract, } 2 \% \text { agar })\left(22{ }^{\circ} \mathrm{C},\right. \\
70 \% \mathrm{RH})\end{array}$ & $0.21 \mathrm{U} / \mathrm{mL}$ (42 days) & Irbe et al. [48] \\
\hline $\begin{array}{l}\text { Trametes versicolor }(\mathrm{L}) \\
\text { Loyd (CTB 863A) }\end{array}$ & $\begin{array}{l}\text { Aspen wood } \\
(5 \% \text { malt extract, } 2 \% \text { agar })\left(22{ }^{\circ} \mathrm{C},\right. \\
70 \% \mathrm{RH})\end{array}$ & $0.30 \mathrm{U} / \mathrm{mL}$ (42 days) & Irbe et al. [48] \\
\hline $\begin{array}{l}\text { Trametes versicolor }(\mathrm{L}) \\
\text { Loyd (CTB 863A) }\end{array}$ & $\begin{array}{l}\text { Alder wood } \\
(5 \% \text { malt extract, } 2 \% \text { agar })\left(22{ }^{\circ} \mathrm{C} \text {, }\right. \\
70 \% \mathrm{RH})\end{array}$ & $0.29 \mathrm{U} / \mathrm{mL}$ (42 days) & Irbe et al. [48] \\
\hline Trametes versicolor СТВ 863 & $\begin{array}{l}\text { Pine wood } \\
\text { (MEA media, agar, colonized with } \\
\text { ring) } \\
\left(22^{\circ} \mathrm{C}, 70 \% \mathrm{RH}\right)\end{array}$ & $0.25 \pm 0.02 \mathrm{U} / \mathrm{mL}$ (10 days) & Elisashvili et al. [49] \\
\hline Trametes versicolor СТВ 863 & $\begin{array}{l}\text { Pine wood } \\
\text { (WB media, agar, colonized with ring) } \\
\left(22^{\circ} \mathrm{C}, 70 \% \mathrm{RH}\right)\end{array}$ & $0.33 \pm 0.01 \mathrm{U} / \mathrm{mL}$ (20 days) & Elisashvili et al. [49] \\
\hline $\begin{array}{l}\text { Trametes versicolor } 159 \\
\quad \text { (Basidiomycota) }\end{array}$ & $\begin{array}{l}\text { TEMPO-oxidized-CNF(0.017 wt } \%) \\
\text { and CNC }\left(0.2 \mathrm{wt}^{\circ}\right) \\
\left(2 \%(w / v) \mathrm{ME}, 25^{\circ} \mathrm{C}, 80 \% \mathrm{RH}\right) \\
\text { (standing cultures) }\end{array}$ & $\sim 20 \pm 5 \mathrm{U} / \mathrm{mL}$ (25 days) & This study \\
\hline $\begin{array}{l}\text { Trametes versicolor } 159 \\
\quad \text { (Basidiomycota) }\end{array}$ & $\begin{array}{l}\text { TEMPO-oxidized CNF }(0.017 \mathrm{wt} \%) \\
\text { and } \mathrm{CNC}(0.2 \mathrm{wt} \%) \\
\left(2 \%(w / v) \mathrm{ME}, 120 \mathrm{rpm} 25^{\circ} \mathrm{C},\right. \\
80 \% \mathrm{RH})\end{array}$ & $\sim 6 \pm 2 \mathrm{U} / \mathrm{mL}$ (14 days) & This study \\
\hline
\end{tabular}


Table 1. Cont.

\begin{tabular}{|c|c|c|c|}
\hline Fungus & Growth Conditions & Endoglucanase Activity & Study \\
\hline $\begin{array}{l}\text { Trametes pubescens } 220 \\
\quad \text { (Basidiomycota) }\end{array}$ & $\begin{array}{l}\text { TEMPO-oxidized CNF(0.017 wt } \%) \\
\text { and } \mathrm{CNC}(0.2 \mathrm{wt} \%) \\
\left(2 \%(w / v) \mathrm{ME}, 25^{\circ} \mathrm{C}, 80 \% \mathrm{RH}\right) \\
\text { (standing cultures) }\end{array}$ & $\sim 16 \pm 3 \mathrm{U} / \mathrm{mL}$ (25 days) & This study \\
\hline $\begin{array}{l}\text { Trametes pubescens } 220 \\
\quad \text { (Basidiomycota) }\end{array}$ & $\begin{array}{l}\text { TEMPO-oxidized CNF(0.017 wt } \%) \\
\text { and CNC }(0.2 \mathrm{wt} \%) \\
\left(2 \%(w / v) \mathrm{ME}, 120 \mathrm{rpm}, 25{ }^{\circ} \mathrm{C} \text {, }\right. \\
80 \% \mathrm{RH})\end{array}$ & $\sim 8 \pm 4 \mathrm{U} / \mathrm{mL}$ (14 days) & This study \\
\hline $\begin{array}{l}\text { Ganoderma adspersum } 003 \\
\text { (Basidiomycota) }\end{array}$ & $\begin{array}{l}\text { TEMPO-oxidized CNF(0.017 wt } \%) \\
\text { and CNC }\left(0.2 w^{\circ} \%\right) \\
\left(2 \%(w / v) \mathrm{ME}, 25^{\circ} \mathrm{C}, 80 \% \mathrm{RH}\right) \\
\text { (standing cultures) }\end{array}$ & $\sim 34 \pm 2 \mathrm{U} / \mathrm{mL}$ (25 days) & This study \\
\hline $\begin{array}{c}\text { Ganoderma adspersum } 003 \\
\text { (Basidiomycota) }\end{array}$ & $\begin{array}{l}\text { TEMPO-oxidized CNF }(0.017 \mathrm{wt} \%) \\
\text { and CNC }(0.2 \mathrm{wt} \%) \\
\left(2 \%(w / v) \mathrm{ME}, 120 \mathrm{rpm}, 25{ }^{\circ} \mathrm{C} \text {, }\right. \\
80 \% \mathrm{RH})\end{array}$ & $\sim 23 \pm 2 \mathrm{U} / \mathrm{mL}$ (14 days) & This study \\
\hline $\begin{array}{l}\text { Ganoderma lipsiense } 646 \\
\text { (Basidiomycota) }\end{array}$ & $\begin{array}{l}\text { TEMPO-oxidized CNF(0.017 wt } \%) \\
\text { and } \mathrm{CNC}(0.2 \mathrm{wt} \%) \\
\left(2 \%(w / v) \mathrm{ME}, 25^{\circ} \mathrm{C}, 80 \% \mathrm{RH}\right) \\
\text { (standing cultures) }\end{array}$ & $\sim 42 \pm 9 \mathrm{U} / \mathrm{mL}$ (25 days) & This study \\
\hline $\begin{array}{l}\text { Ganoderma lipsiense } 646 \\
\text { (Basidiomycota) }\end{array}$ & $\begin{array}{l}\text { TEMPO-oxidized CNF }(0.017 \mathrm{wt} \%) \\
\text { and CNC }(0.2 \mathrm{wt} \%) \\
\left(2 \%(w / v) \mathrm{ME}, 120 \mathrm{rpm}, 25{ }^{\circ} \mathrm{C} \text {, }\right. \\
80 \% \mathrm{RH})\end{array}$ & $\sim 16 \pm 4 \mathrm{U} / \mathrm{mL}$ (25 days) & This study \\
\hline $\begin{array}{l}\text { Rigidoporus vitreus } 643 \\
\text { (Basidiomycota) }\end{array}$ & $\begin{array}{l}\text { TEMPO-oxidized CNF(0.017 wt } \%) \\
\text { and CNC }\left(0.2 \mathrm{wt}^{\circ} \%\right) \\
\left(2 \%(w / v) \mathrm{ME}, 25^{\circ} \mathrm{C}, 80 \% \mathrm{RH}\right) \\
\text { (standing cultures) }\end{array}$ & $\sim 21 \pm 2 \mathrm{U} / \mathrm{mL}$ (25 days) & This study \\
\hline $\begin{array}{l}\text { Rigidoporus vitreus } 643 \\
\text { (Basidiomycota) }\end{array}$ & $\begin{array}{l}\text { TEMPO-oxidized CNF }(0.017 \mathrm{wt} \%) \\
\text { and CNC }(0.2 \mathrm{wt} \%) \\
\left(2 \%(w / v) \mathrm{ME}, 120 \mathrm{rpm}, 25^{\circ} \mathrm{C} \text {, }\right. \\
80 \% \mathrm{RH})\end{array}$ & $\sim 15 \pm 5 \mathrm{U} / \mathrm{mL}$ (25 days) & This study \\
\hline
\end{tabular}

RH refers to relative humidity; ME refers to Malt Extract.

Another enzyme that we analyzed for activity in cultures was laccase. Laccases are multi-copper oxidases that oxidize phenolic and non-phenolic substrates with the concomitant reduction of oxygen to water. Organic and inorganic substrates of this enzyme include ortho-, meta-, and para-substituted compounds with a lone electron pair [29]. Although extracellular laccases are constitutively produced in basidiomycetes under aerobic conditions [50], their production and activities are further stimulated by a variety of compounds including lignin or lignin derivatives such as ferulic acid, guaiacol, veratryl alcohol [51] and also by cellulose [13]. Similar to the endoglucanase results, laccase activities were highest in cultures that were standing compared to those that were shaken throughout the cultivation period. The highest activities of laccase were observed in standing cultures of $T$. versicolor 159 (351 U/L) and R. vitreus 643 (603 U/L) (Figure 3A,B). In the case of T. versicolor 159 , this value is similar to activities obtained with T. versicolor (CBS100.29) cultured with grape seeds (250 U/L) or grape stalks (450 U/L) [52] and T. versicolor 145 cultured with mandarin peels ( $428 \pm 19 \mathrm{U} / \mathrm{L}$ ) (Table 2). Laccase production was higher than observed with the same T. versicolor 159 Empa strain in standing cultures grown with glucose and veratryl alcohol $(122 \pm 24 \mathrm{U} / \mathrm{L})$ or spruce wood sawdust $(198 \pm 44 \mathrm{U} / \mathrm{L})$ (Table 2$)$. Additionally, the laccase activities of $R$. vitreus 643 in standing cultures $(603 \pm 75 \mathrm{U} / \mathrm{L})$ were similar to those observed when the same culture was grown with spruce wood sawdust 
$(755 \pm 148 \mathrm{U} / \mathrm{L})$ [53]. These results show that TEMPO-oxidized CNF and CNC stimulates laccase production in T. versicolor 159 and $R$. vitreus 643 similar to more complex lignocellulosic substrates. Various fungi possess different forms (isoforms) of laccases that are expressed depending on the substrate that these fungi encounter (Kaczmarek et al. [54]). Of the available white-rot fungal genomes, the genomes of T. versicolor and T. pubescens show that these fungi possess 24 and 8 laccase genes respectively (Table S1). It could be that the greater number of laccase genes in $T$. versicolor give it a competitive advantage over other white-rot fungi with less laccase genes if more of these isoforms are produced in response to lignocellulosic compounds. It would be interesting to determine in future experiments which genes, of the available fungal genomes, are expressed in the presence of TEMPO-oxidized CNF and CNC.

Table 2. Comparison of laccase activities of fungi grown in the presence of various lignocellulosic substrates.

\begin{tabular}{|c|c|c|c|}
\hline Fungus & Growth Conditions & Laccase Activity & Study \\
\hline Trametes versicolor IBB 897 & $\begin{array}{l}\text { Glucose medium, submerged fermentation } \\
\text { containing mandarin peels } \\
\left(25^{\circ} \mathrm{C}, 150 \mathrm{rpm}\right)\end{array}$ & $\begin{array}{l}3008 \pm 325 \mathrm{U} / \mathrm{L} \\
\quad(10 \text { days })\end{array}$ & Elisashvili et al. [12] \\
\hline Trametes versicolor IBB 897 & $\begin{array}{l}\text { Glucose medium, submerged fermentation } \\
\text { containing tree leaves }\left(25^{\circ} \mathrm{C}, 150 \mathrm{rpm}\right)\end{array}$ & $\begin{array}{l}769 \pm 84 \mathrm{U} / \mathrm{L} \\
\quad(10 \text { days })\end{array}$ & Ellisashvili et al. [12] \\
\hline Trametes versicolor IBB 897 & $\begin{array}{l}\text { Glucose medium, submerged fermentation } \\
\text { containing apple peels }\left(25^{\circ} \mathrm{C}, 150 \mathrm{rpm}\right)\end{array}$ & $\begin{array}{l}540 \pm 59 \mathrm{U} / \mathrm{L} \\
(10 \text { days })\end{array}$ & Elisashvili et al. [12] \\
\hline Trametes versicolor IBB 897 & $\begin{array}{l}\text { Glucose medium, submerged fermentation } \\
\text { containing banana peels } \\
\left(25^{\circ} \mathrm{C}, 150 \mathrm{rpm}\right)\end{array}$ & $\begin{array}{l}1294 \pm 149 \mathrm{U} / \mathrm{L}(10 \\
\text { days })\end{array}$ & Elisashvili et al. [12] \\
\hline $\begin{array}{l}\text { Trametes versicolor } \\
\quad(\text { CBS100.29) }\end{array}$ & $\begin{array}{l}\text { Glucose medium, containing barley bran } \\
\left(30^{\circ} \mathrm{C}, 150 \mathrm{rpm}\right)\end{array}$ & 639 U/L (37 days) & Lorenzo et al. [52] \\
\hline $\begin{array}{l}\text { Trametes versicolor } \\
\quad(\text { CBS100.29) }\end{array}$ & $\begin{array}{l}\text { Glucose medium, containing grape stalks } \\
\left(30^{\circ} \mathrm{C}, 150 \mathrm{rpm}\right)\end{array}$ & 450 U/L (37 days) & Lorenzo et al. [52] \\
\hline $\begin{array}{l}\text { Trametes versicolor } \\
\quad(\text { CBS100.29) }\end{array}$ & $\begin{array}{l}\text { Glucose medium, containing grape seeds } \\
\left(30^{\circ} \mathrm{C}, 150 \mathrm{rpm}\right)\end{array}$ & 250 U/L (37 days) & Lorenzo et al. [52] \\
\hline Trametes versicolor 775 & $\begin{array}{l}\text { Basal synthetic medium containing CMC } \\
(180 \mathrm{rpm}, \mathrm{RT})\end{array}$ & $\begin{array}{l}131 \pm 3.7 \mathrm{U} / \mathrm{L} \\
(5 \text { days }) \\
136 \pm 12.9 \mathrm{U} / \mathrm{L} \\
\text { (8 days })\end{array}$ & Mikiashvili et al. [55] \\
\hline Trametes versicolor 775 & $\begin{array}{l}\text { Basal synthetic medium containing maltose } \\
(180 \mathrm{rpm}, \mathrm{RT})\end{array}$ & $\begin{array}{l}178 \pm 3.4 \mathrm{U} / \mathrm{L} \\
\quad(5 \text { days }) \\
95 \pm 3.6 \mathrm{U} / \mathrm{L} \\
\quad(8 \text { days })\end{array}$ & Mikiashvili et al. [55] \\
\hline Trametes versicolor 775 & $\begin{array}{l}\text { Basal synthetic medium containing Avicel } \\
(180 \mathrm{rpm}, \mathrm{RT})\end{array}$ & $\begin{array}{l}48 \pm 2.7 \mathrm{U} / \mathrm{L} \\
\quad(5 \text { days }) \\
30 \pm 2.5 \mathrm{U} / \mathrm{L} \\
\quad(8 \text { days })\end{array}$ & Mikiashvili et al. [55] \\
\hline Trametes versicolor 775 & $\begin{array}{l}\text { Basal synthetic medium containing } \\
\text { Cellobiose ( } 180 \mathrm{rpm}, \mathrm{RT})\end{array}$ & $\begin{array}{l}663 \pm 22.2 \mathrm{U} / \mathrm{L} \\
(5 \text { days }) \\
742 \pm 29.8 \mathrm{U} / \mathrm{L} \\
\quad(8 \text { days })\end{array}$ & Mikiashvili et al. [55] \\
\hline Trametes versicolor 775 & $\begin{array}{l}\text { Basal synthetic medium containing } \\
\text { mandarin peels } \\
(180 \mathrm{rpm}, \mathrm{RT})\end{array}$ & $\begin{array}{l}5243 \pm 113 \mathrm{U} / \mathrm{L} \\
(5 \text { days }) \\
3438 \pm 80.9 \mathrm{U} / \mathrm{L} \\
\quad(8 \text { days })\end{array}$ & Mikiashvili et al. [55] \\
\hline Trametes versicolor 145 & $\begin{array}{l}\text { Basal synthetic medium containing CMC } \\
(180 \mathrm{rpm}, \mathrm{RT})\end{array}$ & $\begin{array}{l}27 \pm 2.7 \mathrm{U} / \mathrm{L} \\
(5 \text { days }) \\
35 \pm 2.8 \mathrm{U} / \mathrm{L} \\
\quad(8 \text { days })\end{array}$ & Mikiashvili et al. [55] \\
\hline
\end{tabular}


Table 2. Cont.

\begin{tabular}{|c|c|c|c|}
\hline Fungus & Growth Conditions & Laccase Activity & Study \\
\hline Trametes versicolor 145 & $\begin{array}{l}\text { Basal synthetic medium containing maltose } \\
(180 \mathrm{rpm}, \mathrm{RT})\end{array}$ & $\begin{array}{l}69 \pm 10.3 \mathrm{U} / \mathrm{L} \\
(5 \text { days }) \\
48 \pm 3.5 \mathrm{U} / \mathrm{L} \\
(8 \text { days })\end{array}$ & Mikiashvili et al. [55] \\
\hline Trametes versicolor 145 & $\begin{array}{l}\text { Basal synthetic medium containing Avicel } \\
(180 \mathrm{rpm}, \mathrm{RT})\end{array}$ & $\begin{array}{l}15 \pm 0.1 \mathrm{U} / \mathrm{L} \\
(5 \text { days }) \\
11 \pm 0.5 \mathrm{U} / \mathrm{L} \\
(8 \text { days })\end{array}$ & Mikiashvili et al. [55] \\
\hline Trametes versicolor 145 & $\begin{array}{l}\text { Basal synthetic medium containing } \\
\text { Cellobiose ( } 180 \mathrm{rpm}, \mathrm{RT})\end{array}$ & $\begin{array}{l}34 \pm 4.1 \mathrm{U} / \mathrm{L} \\
\quad(5 \text { days }) \\
26 \pm 3.4 \mathrm{U} / \mathrm{L} \\
\quad(8 \text { days })\end{array}$ & Mikiashvili et al. [55] \\
\hline Trametes versicolor 145 & $\begin{array}{l}\text { Basal synthetic medium containing } \\
\text { mandarin peels } \\
(180 \mathrm{rpm}, \mathrm{RT})\end{array}$ & $\begin{array}{l}428 \pm 19.5 \mathrm{U} / \mathrm{L} \\
(5 \text { days }) \\
79 \pm 2.2 \mathrm{U} / \mathrm{L} \\
\text { (8 days) }\end{array}$ & Mikiashvili et al. [55] \\
\hline $\begin{array}{l}\text { Trametes versicolor }(\mathrm{L}) \text { Loyd } \\
\text { (CTB 863A) }\end{array}$ & $\begin{array}{l}\text { Birch wood } \\
(5 \% \text { malt extract, } 2 \% \text { agar })\left(22{ }^{\circ} \mathrm{C}, 70 \% \mathrm{RH}\right)\end{array}$ & $\begin{array}{l}0.01 \mathrm{U} / \mathrm{mL} \\
\text { (42 days) }\end{array}$ & Irbe et al. [48] \\
\hline $\begin{array}{l}\text { Trametes versicolor }(\mathrm{L}) \text { Loyd } \\
\text { (CTB 863A) }\end{array}$ & $\begin{array}{l}\text { Aspen wood } \\
(5 \% \text { malt extract, } 2 \% \text { agar })\left(22{ }^{\circ} \mathrm{C}, 70 \% \mathrm{RH}\right)\end{array}$ & $\begin{array}{l}0.01 \mathrm{U} / \mathrm{mL} \\
\text { (42 days) }\end{array}$ & Irbe et at. [48] \\
\hline $\begin{array}{l}\text { Trametes versicolor }(\mathrm{L}) \text { Loyd } \\
\text { (CTB 863A) }\end{array}$ & $\begin{array}{l}\text { Alder wood } \\
(5 \% \text { malt extract, } 2 \% \text { agar })\left(22{ }^{\circ} \mathrm{C}, 70 \% \mathrm{RH}\right)\end{array}$ & $\begin{array}{l}0 \mathrm{U} / \mathrm{mL} \\
(42 \text { days })\end{array}$ & Irbe et al. [48] \\
\hline $\begin{array}{l}\text { Trametes versicolor } \\
\text { (Empa strain 159) }\end{array}$ & $\begin{array}{l}\text { Basal synthetic medium containing glucose } \\
\text { and veratryl alcohol } \\
\left(25^{\circ} \mathrm{C} \text {, standing cultures) }\right.\end{array}$ & $\begin{array}{l}122 \pm 24 \mathrm{U} / \mathrm{L} \\
\quad(9 \text { days })\end{array}$ & Ihssen et al. [53] \\
\hline $\begin{array}{l}\text { Trametes versicolor } \\
\text { (Empa strain 159) }\end{array}$ & $\begin{array}{l}\text { Basal synthetic medium containing wood } \\
\text { spruce dust }\left(25^{\circ} \mathrm{C} \text {, standing cultures }\right)\end{array}$ & $\begin{array}{l}198 \pm 44 \mathrm{U} / \mathrm{L} \\
\quad(9 \text { days })\end{array}$ & Ihssen et al. [53] \\
\hline $\begin{array}{l}\text { Trametes versicolor } \\
\text { (Empa strain 159) }\end{array}$ & $\begin{array}{l}\text { TEMPO-oxidized CNF }(0.017 \text { wt } \%) \text { and } \\
\text { CNC }(0.2 \mathrm{wt} \%) \\
(2 \%(w / v) \mathrm{ME}, \\
\left.25^{\circ} \mathrm{C}, 80 \% \mathrm{RH}\right) \\
\text { (standing cultures) }\end{array}$ & $\begin{array}{l}\sim 351 \pm 35 \mathrm{U} / \mathrm{L} \\
\quad(25 \text { days })\end{array}$ & This study \\
\hline $\begin{array}{l}\text { Trametes versicolor } \\
\text { (Empa strain 159) }\end{array}$ & $\begin{array}{l}\text { TEMPO-oxidized CNF }(0.017 \mathrm{wt} \%) \text { and } \\
\text { CNC }(0.2 \mathrm{wt} \%) \\
(2 \%(w / v) \mathrm{ME}, \\
\left.25^{\circ} \mathrm{C}, 80 \% \mathrm{RH}, 120 \mathrm{rpm}\right)\end{array}$ & $\begin{array}{l}\sim 225 \pm 79 \mathrm{U} / \mathrm{L} \\
\quad(14 \text { days })\end{array}$ & This study \\
\hline $\begin{array}{l}\text { ** Trametes pubescens } \\
\text { (Empa strain 220) }\end{array}$ & $\begin{array}{l}\text { Basal synthetic medium containing glucose } \\
\text { and veratryl alcohol } \\
\text { ( } 25^{\circ} \mathrm{C} \text {, standing cultures) }\end{array}$ & $\begin{array}{l}282 \pm 86 \mathrm{U} / \mathrm{L} \\
\quad(9 \text { days })\end{array}$ & Ihssen et al. [53] \\
\hline $\begin{array}{l}\text { ** Trametes pubescens } \\
\text { (Empa strain 220) }\end{array}$ & $\begin{array}{l}\text { Basal synthetic medium containing wood } \\
\text { spruce dust }\left(25^{\circ} \mathrm{C} \text {, standing cultures }\right)\end{array}$ & $\begin{array}{c}53 \pm 20 \mathrm{U} / \mathrm{L} \\
(9 \text { days })\end{array}$ & Ihssen et al. [53] \\
\hline $\begin{array}{l}\text { Trametes pubescens } \\
\text { (Empa strain 220) }\end{array}$ & $\begin{array}{l}\text { TEMPO-oxidized CNF(0.017 wt } \%) \text { and } \\
\mathrm{CNC}(0.2 \mathrm{wt} \%)(2 \%(w / v) \mathrm{ME} \text {, } \\
\left.25^{\circ} \mathrm{C}, 80 \% \mathrm{RH}\right) \\
\text { (standing cultures) }\end{array}$ & $\begin{array}{l}\sim 30 \pm 16 \mathrm{U} / \mathrm{L} \\
\quad(25 \text { days })\end{array}$ & This study \\
\hline $\begin{array}{l}\text { Trametes pubescens } \\
\text { (Empa strain 220) }\end{array}$ & $\begin{array}{l}\text { TEMPO-oxidized-CNF }(0.017 \mathrm{wt} \%) \text { and } \\
\text { CNC }(0.2 \mathrm{wt} \%) \\
(2 \%(w / v) \mathrm{ME}, \\
\left.25^{\circ} \mathrm{C}, 80 \% \mathrm{RH}, 120 \mathrm{rpm}\right)\end{array}$ & $\begin{array}{l}\sim 110 \pm 71 \mathrm{U} / \mathrm{L} \\
\quad(14 \text { days })\end{array}$ & This study \\
\hline $\begin{array}{l}\text { Rigidoporus vitreus } \\
\text { (Empa strain 642) }\end{array}$ & $\begin{array}{l}\text { Basal synthetic medium containing glucose } \\
\text { and veratryl alcohol } \\
\text { ( } 25^{\circ} \mathrm{C} \text {, standing cultures) }\end{array}$ & $\begin{array}{c}2128 \pm 252 \mathrm{U} / \mathrm{L} \\
(9 \text { days })\end{array}$ & Ihssen et al. [53] \\
\hline
\end{tabular}


Table 2. Cont.

\begin{tabular}{|c|c|c|c|}
\hline Fungus & Growth Conditions & Laccase Activity & Study \\
\hline $\begin{array}{l}\text { Rigidoporus vitreus } \\
\text { (Empa strain 642) }\end{array}$ & $\begin{array}{l}\text { Basal synthetic medium containing wood } \\
\text { spruce dust }\left(25^{\circ} \mathrm{C} \text {, standing cultures }\right)\end{array}$ & $\begin{array}{l}755 \pm 148 \mathrm{U} / \mathrm{L} \\
\text { (9 days) }\end{array}$ & Ihssen et al. [53] \\
\hline $\begin{array}{l}\text { * Rigidoporus vitreus } \\
\text { (Empa strain 643) }\end{array}$ & $\begin{array}{l}\text { TEMPO-oxidized-CNF }(0.017 \mathrm{wt} \%) \text { and } \\
\mathrm{CNC}(0.2 \mathrm{wt} \%) \\
(2 \%(w / v) \mathrm{ME}, \\
\left.25^{\circ} \mathrm{C}, 80 \% \mathrm{RH}\right) \\
\text { (standing cultures) }\end{array}$ & $\begin{array}{l}\sim 603 \pm 75 \mathrm{U} / \mathrm{L} \\
\quad(25 \text { days })\end{array}$ & This study \\
\hline $\begin{array}{l}\text { * Rigidoporus vitreus } \\
\text { (Empa strain 643) }\end{array}$ & $\begin{array}{l}\text { TEMPO-oxidized-CNF }(0.017 \mathrm{wt} \%) \text { and } \\
\text { CNC }(0.2 \mathrm{wt} \%) \\
(2 \%(w / v) \mathrm{ME}, \\
\left.25^{\circ} \mathrm{C}, 80 \% \mathrm{RH}, 120 \mathrm{rpm}\right)\end{array}$ & $\begin{array}{l}\sim 238 \pm 32 \mathrm{U} / \mathrm{L} \\
\quad(14 \text { days })\end{array}$ & This study \\
\hline $\begin{array}{l}\text { + Ganoderma lipsiense } \\
\text { (Empa strain 646) }\end{array}$ & $\begin{array}{l}\text { Basal synthetic medium containing glucose } \\
\text { and veratryl alcohol } \\
\left(25^{\circ} \mathrm{C} \text {, standing cultures) }\right.\end{array}$ & $\begin{array}{l}104 \pm 18 \mathrm{U} / \mathrm{L} \\
\quad(9 \text { days })\end{array}$ & Ihssen et al. [53] \\
\hline $\begin{array}{l}\text { + Ganoderma lipsiense } \\
\text { (Empa strain 646) }\end{array}$ & $\begin{array}{l}\text { Basal synthetic medium containing wood } \\
\text { spruce dust }\left(25^{\circ} \mathrm{C} \text {, standing cultures }\right)\end{array}$ & $\begin{array}{l}18 \pm 15 \mathrm{U} / \mathrm{L} \\
\text { (9 days) }\end{array}$ & Ihssen et al. [53] \\
\hline $\begin{array}{l}\text { Ganoderma lipsiense } \\
\text { (Empa strain 646) }\end{array}$ & $\begin{array}{l}\text { TEMPO-oxidized CNF }(0.017 \mathrm{wt} \%) \text { and } \\
\mathrm{CNC}(0.2 \mathrm{wt} \%) \\
(2 \%(w / v) \mathrm{ME}, \\
\left.25^{\circ} \mathrm{C}, 80 \% \mathrm{RH}\right) \\
\text { (standing cultures) }\end{array}$ & $\begin{array}{l}\sim 4 \pm 0 \mathrm{U} / \mathrm{L} \\
\text { (14 days) }\end{array}$ & This study \\
\hline $\begin{array}{l}\text { Ganoderma lipsiense } \\
\text { (Empa strain 646) }\end{array}$ & $\begin{array}{l}\text { TEMPO-oxidized CNF(0.017 wt } \%) \text { and } \\
\mathrm{CNC}(0.2 \mathrm{wt} \%)(2 \%(w / v) \mathrm{ME}, \\
\left.25^{\circ} \mathrm{C}, 80 \% \mathrm{RH}, 120 \mathrm{rpm}\right)\end{array}$ & $\begin{array}{l}\sim 2 \pm 1 \mathrm{U} / \mathrm{L} \\
\text { (11 days) }\end{array}$ & This study \\
\hline $\begin{array}{l}¥ \text { Ganoderma adspersum } \\
\text { (Empa strain 003) }\end{array}$ & $\begin{array}{l}\text { TEMPO-oxidized CNF }(0.017 \mathrm{wt} \%) \text { and } \\
\mathrm{CNC}(0.2 \mathrm{wt} \%) \\
(2 \%(w / v) \mathrm{ME}, \\
\left.25^{\circ} \mathrm{C}, 80 \% \mathrm{RH}\right) \\
\text { (standing cultures) }\end{array}$ & $\begin{array}{l}\sim 95 \pm 31 \mathrm{U} / \mathrm{L} \\
\quad(25 \text { days })\end{array}$ & This study \\
\hline $\begin{array}{l}¥ \text { Ganoderma adspersum } \\
\text { (Empa strain 003) }\end{array}$ & $\begin{array}{l}\text { TEMPO-oxidized CNF(0.017 wt } \%) \text { and } \\
\text { CNC }(0.2 \mathrm{wt} \%) \\
(2 \%(w / v) \mathrm{ME}, \\
\left.25^{\circ} \mathrm{C}, 80 \% \mathrm{RH}, 120 \mathrm{rpm}\right)\end{array}$ & $\begin{array}{l}\sim 19 \pm 14 \mathrm{U} / \mathrm{L} \\
\quad(25 \text { days })\end{array}$ & This study \\
\hline
\end{tabular}

RH refers to relative humidity; RT refers to room temperature; * Rigidoporus vitreus 643 is the same as 642 reported in Ihssen et al. 2011; ** Trametes pubescens 220 is mislabeled in Ihssen et al. 2011 as 568; $¥$ Ganoderma adspersum 646 is the same as strain 647 reported in Ihssen et al. 2011; † Ganoderma lipsiense 646 is mislabeled in Ihnssen et al. 2011 as Ganoderma adspersum 647.

Previous studies have shown that depending on the concentration and type of nitrogen source (organic or inorganic) provided to white-rot fungi during growth, it can either antagonize or stimulate the production of lignocellulolytic enzymes [11,56-58] Ureases are nickel-containing enzymes that hydrolyze urea into ammonia and carbamate during nitrogen metabolism in fungi and other prokaryotes $[59,60]$. Increasing concentrations of urease in all standing cultures show that cells were making use of urea. Fungal cells were likely metabolizing nitrogen compounds present in the malt extract. Under the conditions in this study, both Ganoderma strains and R. vitreus appear to have benefited most from the presence of urea (Figure 5). These fungi could have been using the nitrogen source for either biomass growth or synthesis of lignocellulolytic enzymes.

Detection of low levels of G6P in culture supernatants (Figure 5) implies that cell lysis occurred to some extent during sampling or centrifugation steps. Moreover, these low concentrations of G6P suggest that glucose present in the media was metabolized by fungal cells. G6P is the product of phosphorylation of glucose to G6P by the enzyme hexokinase as part of the glycolysis pathway in prokaryotic cells [61]. In this study, the metabolized glucose could have come from the malt extract media [38] or it could have been produced from 
the breakdown of cellobiose to glucose by $\beta$-glucosidase enzymes outside the cell $[6,62]$. During white-rot cellulose degradation, cellulose is first degraded outside the fungal cell to cellulooligosaccharides (by endoglucanases). Next, cellulooligosaccharides are degraded into cellobiose (by cellobiohydrolases) and finally into glucose by $\beta$-glucosidases [63]. Glucose is then taken up into cells where it undergoes further metabolism via the glycolysis pathway for cell energy production in the form of ATP [61]. High glucose concentrations (e.g., >1 mM) have been shown to inhibit enzymes in white-rot fungi involved in cellulose degradation including $\beta$-glucosidases $[62,64,65]$. Our results show that the presence of glucose did not interfere with endoglucanase production by all five white-rot fungi (Figure 2).

These results highlight the potential use of these white-rot fungi in biotechnological applications involving TEMPO-oxidized $\mathrm{CNF}$ and $\mathrm{CNC}$ as a substrate. The white-rot fungi in this study could be used for biodegradation of TEMPO-oxidized and CNF materials, for example [66]. Another possibility is using these white-rot fungi to stimulate laccase and urease production and incorporation into TEMPO-oxidized materials for energy production $[67,68]$.

\section{Conclusions}

The lack of inhibition of endoglucanase, laccase, and urease observed in this study when the white-rot fungi T. versicolor 159, T. pubescens 220, G. adspersum 003, G. lipsiense 646, and R. vitreus 643 were grown in the presence of malt extract and TEMPO-oxidized CNF and CNC, shows that TEMPO-oxidized cellulose materials are biocompatible with the fungi studied here. Endoglucanases are likely involved in the cleavage of $\beta-1,4$-glycosidic linkages of CNF and CNC. Urease activities indicate active nitrogen uptake from the malt extract media. Glucose concentrations appear too low to inhibit cellulase activities in standing cultures. Cultivation under long-term static conditions resulted in higher enzyme production possibly due to greater contact time between cells and cellulose material. These results indicate that TEMPO-oxidized CNF and CNC would be an excellent candidate for bioremediation or enzymatic applications involving these fungi.

Supplementary Materials: The following are available online at https:/ / www.mdpi.com/2309-608 X/7/3/222/s1, Figure S1: Growth rates of T. versicolor 159 in the presence of different percentages of malt extract (ME) and glucose (GL), Figure S2: Growth rates of T. pubescens 220 in the presence of different percentages of malt extract (ME) and glucose (GL), Figure S3: Growth rates of G. adspersum 003 in the presence of different percentages of malt extract (ME) and glucose (GL), Figure S4: Growth rates of $G$. lipsiense 646 in the presence of different percentages of malt extract (ME) and glucose (GL), Figure S5: Growth rates of $R$. vitreus 643 in the presence of different percentages of malt extract (ME) and glucose (GL), Table S1: Various genes for laccase production found in the genome of T. versicolor and T. pubescens based on the UniProt server (uniprot.org, accessed on 15 February 2021).

Author Contributions: Conceptualization, C.R., F.W.M.R.S. and J.R.; Methodology, C.R. and J.R.; Formal Analysis, C.R.; Investigation, C.R. and J.R.; Resources, F.W.M.R.S.; Writing-Original Draft Preparation, C.R.; Writing—Review \& Editing, C.R., A.P., G.N., F.W.M.R.S., and J.R.; Supervision, J.R. Project Administration, J.R.; Funding Acquisition, J.R. All authors have read and agreed to the published version of the manuscript.

Funding: This study was financed by the Gebert Rüf Stifung, Switzerland (Project num. GRS-08/19).

Informed Consent Statement: Not applicable.

Acknowledgments: The authors would like to thank Gilberto Siqueira for his help with preparation of the cellulose material used in this study.

Conflicts of Interest: The authors declare no conflict of interest.

\section{References}

1. Pathak, P.; Kaur, P.; Bhardwaj, N.K. Chapter 6. Microbial enzymes for pulp and paper industry. In Microbial Biotechnology: An Interdiciplinary Approach; Shukla, P., Ed.; CRC Press Taylor and Francis Group: Boca Raton, FL, USA, 2017; pp. 163-240. 
2. Wesenberg, D.; Kyriakides, I.; Agathos, S.N. White-rot fungi and their enzymes for the treatment of industrial dye effluents. Biotechnol. Adv. 2003, 22, 161-187. [CrossRef]

3. Mayolo-Deloisa, K.; González-González, M.; Rito-Palomares, M. Laccases in food industry: Bioprocessing, potential industrial and biotechnological applications. Front. Bioeng. Biotechnol. 2020, 8, 1-8. [CrossRef]

4. Schwarze, F.W.M.R. Wood decay under the microscope. Fungal Biol. Rev. 2007, 21, 133-170. [CrossRef]

5. Andlar, M.; Rezić, T.; Marđetko, N.; Kracher, D.; Ludwig, R.; Šantek, B. Lignocellulose degradation: An overview of fungi and fungal enzymes involved in lignocellulose degradation. Eng. Life Sci. 2018, 18, 768-778. [CrossRef]

6. Manavalan, T.; Manavalan, A.; Heese, K. Characterization of lignocellulolytic enzymes from white-rot fungi. Curr. Microbiol. 2015, 70, 485-498. [CrossRef]

7. Okal, E.J.; Aslam, M.M.; Karanja, J.K.; Nyimbo, W.J. Mini review: Advances in understanding regulation of cellulase enzyme in white-rot basidiomycetes. Microb. Pathog. 2020, 147, 104410. [CrossRef]

8. Arora, D.S.; Gill, P.K. Laccase production by some white rot fungi under different nutritional conditions. Bioresour. Technol. 2000, 73, 283-285. [CrossRef]

9. Satyamurthy, P.; Jain, P.; Karande, V.S.; Nadanathangam, V. Nanocellulose induces cellulase production in Trichoderma reesei. Process Biochem. 2016, 51, 1452-1457. [CrossRef]

10. Niranjane, A.P.; Madhou, P.; Stevenson, T.W. The effect of carbohydrate carbon sources on the production of cellulase by Phlebia gigantea. Enzyme Microb. Technol. 2007, 40, 1464-1468. [CrossRef]

11. Kachlishvili, E.; Penninckx, M.J.; Tsiklauri, N.; Elisashvili, V. Effect of nitrogen source on lignocellulolytic enzyme production by white-rot basidiomycetes under solid-state cultivation. World J. Microbiol. Biotechnol. 2006, 22, 391-397. [CrossRef]

12. Elisashvili, V.; Kachlishvili, E.; Penninckx, M. Effect of growth substrate, method of fermentation, and nitrogen source on lignocellulose-degrading enzymes production by white-rot basidiomycetes. J. Ind. Microbiol. Biotechnol. 2008, 35, 1531-1538. [CrossRef]

13. Srinivasan, C.; D'Souza, T.M.; Boominathan, K.; Reddy, C.A. Demonstration of laccase in the white rot basidiomycete Phanerochaete chrysosporium BKM-F1767. Appl. Environ. Microbiol. 1995, 61, 4274-4277. [CrossRef]

14. Kobakhidze, A.; Asatiani, M.; Kachlishvili, E.; Elisashvili, V. Induction and catabolite repression of cellulase and xylanase synthesis in the selected white-rot basidiomycetes. Ann. Agrar. Sci. 2016, 14, 169-176. [CrossRef]

15. Pertile, G.; Panek, J.; Oszust, K.; Siczek, A.; Oleszek, M.; Gryta, A.; Frąc, M. Effect of different organic waste on cellulose-degrading enzymes secreted by Petriella setifera in the presence of cellobiose and glucose. Cellulose 2019, 26, 7905-7922. [CrossRef]

16. Sun, X.; Zhang, R.; Zhang, Y. Production of lignocellulolytic enzymes by Trametes gallica and detection of polysaccharide hydrolase and laccase activities in polyacrylamide gels. J. Basic Microbiol. 2004, 44, 220-231. [CrossRef]

17. Suzuki, H.; Igarashi, K.; Samejima, M. Real-time quantitative analysis of carbon catabolite derepression of cellulolytic genes expressed in the basidiomycete Phanerochaete chrysosporium. Appl. Microbiol. Biotechnol. 2008, 80, 99-106. [CrossRef]

18. Jämsä, M.; Kosourov, S.; Rissanen, V.; Hakalahti, M.; Pere, J.; Ketoja, J.A.; Tammelin, T.; Allahverdiyeva, Y. Versatile templates from cellulose nanofibrils for photosynthetic microbial biofuel production. J. Mater. Chem. A 2018, 6, 5825-5835. [CrossRef]

19. Serra, A.; González, I.; Oliver-Ortega, H.; Tarrès, Q.; Delgado-Aguilar, M.; Mutjé, P. Reducing the amount of catalyst in TEMPO-oxidized cellulose nanofibers: Effect on properties and cost. Polymers 2017, 9, 557. [CrossRef]

20. Mycobank: Ganoderma Lipsiense. Available online: https://www.mycobank.org/page/Namedetailspage/name/ Ganodermaapplanatum (accessed on 2 March 2021).

21. Atkinson, B.G.F. Ganoderma lipsiense. Ann. Mycol. 1908, 6, [MB\#148315].

22. Mycobank: Physisporinus vitreus. Available online: https://www.mycobank.org/page/Namedetailspage/name/ Physisporinusvitreus (accessed on 2 March 2021).

23. Donk, M.A. Notes on European polypores-I. Persoonia 1966, 4, 337-343.

24. Saito, T.; Kimura, S.; Nishiyama, Y.; Isogai, A. Cellulose nanofibers prepared by TEMPO-mediated oxidation of native cellulose. Biomacromolecules 2007, 8, 2485-2491. [CrossRef] [PubMed]

25. Weishaupt, R.; Siqueira, G.; Schubert, M.; Tingaut, P.; Maniura-Weber, K.; Zimmermann, T.; Thöny-Meyer, L.; Faccio, G.; Ihssen, J. TEMPO-oxidized nanofibrillated cellulose as a high density carrier for bioactive molecules. Biomacromolecules 2015, 16, 3640-3650. [CrossRef]

26. Rahman, M.S.; Fernando, S.; Ross, B.; Wu, J.; Qin, W. Endoglucanase (eg) activity assays. Methods Mol. Biol. 2018, 1796, 169-183. [CrossRef]

27. Gross, K.C. A rapid and sensitive spectrophotometric method for assaying polygalacturonase using 2-cyanoacetamide. HortScience 1982, 17, 933-934. [CrossRef]

28. Jurick, W.M.; Vico, I.; Whitaker, B.D.; Gaskins, V.L.; Janisiewicz, W.J. Application of the 2-cyanoacetamide method for spectrophotometric assay of cellulase enzyme activity. Plant Pathol. J. 2012, 11, 38-40. [CrossRef]

29. Fu, K.; Fu, S.; Zhan, H.; Zhou, P.; Liu, M.; Liu, H. A newly isolated wood-rot fungus for laccase production in submerged cultures. BioResources 2013, 8, 1385-1397. [CrossRef]

30. Rehmann, L.; Ivanova, E.; Ferguson, J.L.; Gunaratne, H.Q.N.; Seddon, K.R.; Stephens, G.M. Measuring the effect of ionic liquids on laccase activity using a simple, parallel method. Green Chem. 2012, 14, 725-733. [CrossRef]

31. Berthelot, M. Correspondence-'Violet D'aniline'; Repertoire de chimie applique. Société Chimique de Paris 1859, 1, 284. 
32. Jo, W.-S.; Kang, M.-J.; Choi, S.-Y.; Yoo, Y.-B.; Seok, S.-J.; Jung, H.-Y. Culture conditions for mycelial growth of Coriolus versicolor. Mycobiology 2010, 38, 195. [CrossRef] [PubMed]

33. Jo, W.-S.; Cho, Y.-J.; Cho, D.-H.; Park, S.-D.; Yoo, Y.-B.; Seok, S.-J. Culture conditions for the mycelial growth of Ganoderma applanatum. Mycobiology 2009, 37, 94. [CrossRef]

34. Badalyan, S.M.; Gharibyan, N.G.; Iotti, M. Morphological and ecological screening of different collections of medicinal white-rot bracket fungus Ganoderma adspersum (Schulzer) Donk (Agaricomycetes, Polyporales). Ital. J. Mycol. 2019, 48, 1-15.

35. Schubert, M.; Dengler, V.; Mourad, S.; Schwarze, F.W.M.R. Determination of optimal growth parameters for the bioincising fungus physisporinus vitreus by means of response surface methodology. J. Appl. Microbiol. 2009, 106, 1734-1742. [CrossRef]

36. Levin, L.; Melignani, E.; Ramos, A.M. Effect of nitrogen sources and vitamins on ligninolytic enzyme production by some white-rot fungi. Dye decolorization by selected culture filtrates. Bioresour. Technol. 2010, 101, 4554-4563. [CrossRef]

37. Elisashvili, V.I.; Kachlishvili, E.T.; Wasser, S.P. Carbon and nitrogen source effects on basidiomycetes exopolysaccharide production. Appl. Biochem. Microbiol. 2009, 45, 531-535. [CrossRef]

38. Merck Malt Extract. In Microbiology Manual 12 Edition; Merck: Kenilworth, NJ, USA, 2010; p. 688.

39. Arora, D.S.; Gill, P.K. Effects of various media and supplements on laccase production by some white rot fungi. Bioresour. Technol. 2001, 77, 89-91. [CrossRef]

40. Haars, A.; Tautz, D.; Hüttermann, A. Bioconversion of organosoluble lignins by different types of fungi. Resour. Conserv. 1986, 13, 37-51. [CrossRef]

41. Cairns, T.C.; Zheng, X.; Zheng, P.; Sun, J.; Meyer, V. Moulding the mould: Understanding and reprogramming filamentous fungal growth and morphogenesis for next generation cell factories. Biotechnol. Biofuels 2019, 12, 1-18. [CrossRef]

42. Basu, S.N.; Pal, P.N. An unfavourable effect of shaking on fungal cellulases. Nature 1956, 178, 312-313. [CrossRef]

43. Ganesh, K.; Joshi, J.B.; Sawant, S.B. Cellulase deactivation in a stirred reactor. Biochem. Eng. J. 2000, 4, 137-141. [CrossRef]

44. Reese, E.T.; Ryu, D.Y. Shear inactivation of cellulase of Trichoderma reesei. Enzyme Microb. Technol. 1980, 2, 239-240. [CrossRef]

45. Sachse, H.; Kude, J.; Kerns, G.; Berger, R. Production of cellulase in a rotating disc fermenter using immobilized Trichoderma reesei cells. Acta Biotechnol. 1990, 10, 523-529. [CrossRef]

46. Metreveli, E.; Kachlishvili, E.; Singer, S.W.; Elisashvili, V. Alteration of white-rot basidiomycetes cellulase and xylanase activities in the submerged co-cultivation and optimization of enzyme production by Irpex lacteus and Schizophyllum commune. Bioresour. Technol. 2017, 241, 652-660. [CrossRef] [PubMed]

47. Liu, H.Q.; Feng, Y.; Zhao, D.Q.; Jiang, J.X. Evaluation of cellulases produced from four fungi cultured on furfural residues and microcrystalline cellulose. Biodegradation 2012, 23, 465-472. [CrossRef] [PubMed]

48. Irbe, I.; Elisashvili, V.; Asatiani, M.D.; Janberga, A.; Andersone, I.; Andersons, B.; Biziks, V.; Grinins, J. Lignocellulolytic activity of Coniophora puteana and Trametes versicolor in fermentation of wheat bran and decay of hydrothermally modified hardwoods. Int. Biodeterior. Biodegrad. 2014, 86, 71-78. [CrossRef]

49. Elisashvili, V.; Irbe, I.; Andersone, I.; Andersons, B.; Tsiklauri, N. Hydrolytic enzyme activity of EN113 standard basidiomycetes in the fermentation of lignocellulosic material and wood colonization. Holzforschung 2012, 66, 841-847. [CrossRef]

50. Bollag, J.M.; Leonowicz, A. Comparative studies of extracellular fungal laccases. Appl. Environ. Microbiol. 1984, 48, 849-854. [CrossRef]

51. Revankar, M.S.; Lele, S.S. Enhanced production of laccase using a new isolate of white rot fungus WR-1. Process Biochem. 2006, 41, 581-588. [CrossRef]

52. Lorenzo, M.; Moldes, D.; Rodríguez Couto, S.; Sanromán, A. Improving laccase production by employing different lignocellulosic wastes in submerged cultures of Trametes versicolor. Bioresour. Technol. 2002, 82, 109-113. [CrossRef]

53. Ihssen, J.; Schubert, M.; Schwarze, F.W.M.R.; Thöny-Meyer, L. Efficient production of $\mathrm{Al}(\mathrm{OH}) 3$-immobilized laccase with a Heterobasidion annosum strain selected by microplate screening. J. Appl. Microbiol. 2011, 110, 924-934. [CrossRef]

54. Kaczmarek, M.; Kwiatos, N.; Szczesna-Antczak, M.; Bielecki, S. Laccases—enzymes with an unlimited potential. Biotechnol. Food Sci. 2017, 2017, 41-70.

55. Mikiashvili, N.; Elisashvili, V.; Wasser, S.; Nevo, E. Carbon and nitrogen sources influence the ligninolytic enzyme activity of Trametes versicolor. Biotechnol. Lett. 2005, 27, 955-959. [CrossRef]

56. Jing, D. Improving the simultaneous production of laccase and lignin peroxidase from Streptomyces lavendulae by medium optimization. Bioresour. Technol. 2010, 101, 7592-7597. [CrossRef]

57. Collins, P.J.; Field, J.A.; Teunissen, P.; Dobson, A.D.W. Stabilization of lignin peroxidases in white rot fungi by tryptophan. Appl. Environ. Microbiol. 1997, 63, 2543-2548. [CrossRef]

58. Kaal, E.E.J.; Field, J.A.; Joyce, T.W. Increasing ligninolytic enzyme activities in several white-rot Basidiomycetes by nitrogensufficient media. Bioresour. Technol. 1995, 53, 133-139. [CrossRef]

59. Krajewska, B.; Ureases, I. Functional, catalytic and kinetic properties: A review. J. Mol. Catal. B Enzym. 2009, 59, 9-21. [CrossRef]

60. Mobley, H.L.T.; Island, M.D.; Hausinger, R.P. Molecular biology of microbial ureases. Microbiol. Rev. 1995, 59, 451-480. [CrossRef]

61. McCullough, W.; Roberts, C.F.; Osmani, S.A.; Scrutton, M.C. Chapter 9: Regulation of carbon metabolism in filamentous fungi. In Carbohydrate Metabolism in Cultured Cells; Morgan, M.J., Ed.; Plenum Press: New York, NY, USA, 1986; p. 634. ISBN 9783540773405.

62. Smith, M.H.; Gold, M.H. Phanerochaete chrysosporium $\beta$-glucosidases: Induction, cellular localization, and physical characterization Appl. Environ. Microbiol. 1979, 37, 938-942. [CrossRef] 
63. Manavalan, T.; Manavalan, A.; Thangavelu, K.P.; Heese, K. Characterization of a novel endoglucanase from Ganoderma lucidum. J. Basic Microbiol. 2015, 55, 761-771. [CrossRef]

64. Daly, P.; Peng, M.; Di Falco, M.; Lipzen, A.; Wang, M.; Ng, V.; Grigoriev, I.V.; Tsang, A.; Mäkelä, M.R.; de Vries, R.P. Glucosemediated repression of plant biomass utilization in the white-rot fungus. Appl. Environ. Microbiol. 2019, 85, 1-15. [CrossRef]

65. Nisyzawa, T.; Suzuki, H.; Nisizawa, K. Catabolite repression of cellulase formation in Trichoderma viride. J. Biochem. 1972, 71, 999-1007. [CrossRef]

66. Isogai, A.; Saito, T.; Fukuzumi, H. TEMPO-oxidized cellulose nanofibers. Nanoscale 2011, 3, 71-85. [CrossRef] [PubMed]

67. Wu, C.; Liu, X.W.; Li, W.W.; Sheng, G.P.; Zang, G.L.; Cheng, Y.Y.; Shen, N.; Yang, Y.P.; Yu, H.Q. A white-rot fungus is used as a biocathode to improve electricity production of a microbial fuel cell. Appl. Energy 2012, 98, 594-596. [CrossRef]

68. Magotra, V.K.; Kumar, S.; Kang, T.W.; Inamdar, A.I.; Aqueel, A.T.; Im, H.; Ghodake, G.; Shinde, S.; Waghmode, D.P.; Jeon, H.C. Compost soil microbial fuel cell to generate power using urea as fuel. Sci. Rep. 2020, 10, 1-9. [CrossRef] [PubMed] 